\title{
解説・資料 \\ 新鉱物苦土定永閃石及びソーダ金雲母の記載

\author{
Description of magnesiosadanagaite and aspidolite, \\ two newly approved mineral species
}

坂野 靖行 (Yasuyuki BANNO)*

Keywords: Magnesiosadanagaite, Aspidolite, New mineral species, Sakurai Medal

\section{I. はじめに}

このたびは, 栄えある櫻井賞を頂きありがとうござい ました。第 36 人目の受賞者とのことです。編集部からの 依頼により,ここに受賞対象鉱物である岐阜県春日村 (現 揖斐川町春日) 産ソーダ金雲母 (aspidolite) (Banno $e t$ $a l ., 2005)$ と光れに随伴する苦土定永閃石 (magnesiosadanagaite) (Banno et al., 2004)の記載研究の経緯を紹介させて いただきます。これらの鉱物の名前は私が研究を開始す る前から既に存在していました。しかしよくよく考えて みるとこれらの鉱物は, 名前はあるものの, 鉱物の種と しては確立されていなかったのです。もちろん最初から 兴のように考えていたわけではなく，いろんな人からの こ意見により認識できるようになったのですが。世の中 にはこのような変わったケースの新鉣物記載もあるのだ ということを知っていただければ幸いです。

\section{II. 苦土定永閃石}

もともと magnesiosadanagaite という鉱物名は, Shimazaki et al. (1984) により記載された愛媛県明神島産の新種 の角閃石に対して与えられたもので, 弚れの化学式は $(\mathrm{K}, \mathrm{Na}) \mathrm{Ca}_{2}\left(\mathrm{Mg}_{2} \mathrm{Fe}^{2+}, \mathrm{Al}, \mathrm{Fe}^{3+}, \mathrm{Ti}\right)_{5}(\mathrm{Si}, \mathrm{Al})_{8} \mathrm{O}_{22}(\mathrm{OH})_{2}$ で $\mathrm{Si}<5.5$ apfu という条件がついています。つまり珪素に極めて乏 しいCa 角閃石ということです。鉱物名は東京大学の定永 両一先生にちなみます。关の後 1997 年になって角閃石の 命名規約が大きく改訂されました。この新しい規約によ ると, magnesiosadanagaite は A サイトがNaに富む $\mathrm{Si}$ に乏 しい $(\mathrm{Si}<5.5 \mathrm{apfu}) \mathrm{Ca}$ 角閃石で, 弚の理想化学式は $\mathrm{NaCa}_{2}\left[\mathrm{Mg}_{3}\left(\mathrm{Al}_{1}, \mathrm{Fe}^{3+}\right)_{2}\right] \mathrm{Si}_{5} \mathrm{Al}_{3} \mathrm{O}_{22}(\mathrm{OH})_{2}$ と定義されました。さ らにこの規約では prefix (接頭辞; 例えば fluoro, potassic 等)
か設定されました。例えば K > 0.5 apfu であるならば，名 前の頭に potassic を付け，別種とみなすということです。 この新しい定義に従うと原記載の“ magnesiosadanagaite” は K に富むため, potassic-magnesiosadanagaite と再定義さ れることになります。

私が春日村産角閃石を調べることになったのは, 知り 合いの鉱物愛好家 (神谷俊昭氏, 山田滋夫氏) から鑑定依 頼があったからです。春日村にはドロマイトスカルンが 分布しており，各種のスカルン鉱物が産することで有名 です。まずは薄片をつくり，EPMA 分析を行いました。 薄片を見るとコアとリムとで色が違っていました。分析 の結果, コアは pargasite で, リムが新しく定義された magnesiosadanagaiteに相当するものなのですが，最初に分 析した時は新規約発表前の1993年で，产の時は $\mathrm{Na}$ に富む magnesiosadanagaite と呼んでいました。钅の後研究が中断 している間に新命名規約が発表されました。私は「新命名 規約には magnesiosadanagaite がリストアップされている ので, これは種として確立している」と考えました。新種 ではないもののこれの新しいデータを出すことは多少な りとも意味があると考え，2000 年から論文執筆の準備を 進めることにしました。幸いにも国立科学博物館の松原 聰先生, 宮脇律郎先生と共同研究していただけること になり，私の不得意分野である crystallography に関する部 分のデータを得ることができました。また信州大学の牧 野州明先生には結晶構造解析に関して相談に乗っていた だきました。データはすべて光ろったので論文をしあげ て, 国際誌へ投稿しました。2002 年 8 月に査読結果が 戻ってきました。査読者の一人オベルティ教授のコメン 卜を読んで驚きました。弚れには「この鉱物は新鉱物であ るから, 論文公表の前に, IMA 新鉱物·鉱物名委員会の承

doi:10.2465/gkk.36.187

(平成 19 年 11 月 7 日受付, 平成 19 年 11 月 15 日受理)

* 産業技術総合研究所 地質情報研究部門, 干305-8567 つくば市東 1-1-1

* Institute of Geology and Geoinformation, National Institute of Advanced Industrial Science and Technology (AIST), 1 - 1 - 1 Higashi, Tsukuba 305-8567, Japan E-mail: y-banno@aist.go.jp 
認を得なければならない」というようなことが書かれてい たからです。確かに新しく定義された magnesiosadanagaite に対応する角閃石で化学組成とX線データを含んだ記載 論文は公表されていません。光して命名規約はあくまで も規約であって，既に名前がリストアップされていても， 種として承認されていないものがあるということに気が つきました。光して共同研究者の方々と相談の結果, 新 鉱物·鉱物名委員会へ magnesiosadanagaite の申請書を送る ことになり，2003 年の 1 月に無事承認されました。これ で査読者からの指摘をクリアすることができ，原稿を新 鉱物の記載論文として体裁を整えて再投稿することがで きました。

\section{III. ソーダ金雲母}

Aspidolite はオーストリアで発見された鉱物で, 黑雲母 一金雲母系列に属する $\mathrm{Na}$ と $\mathrm{Mg}$ に富む雲母として記載さ れました (von Kobell, 1869)。鉱物名は結晶の形態から “盾のような”とういうギリシャ語“ aspidos”にちなむと のことです。後に光の化学組成から aspidolite は phlogopite の Na 置換体であると解釈されました。1980年にアルジェ リアより phlogopite の Na 置換体か報告され sodium phlogopite と記述されました (Schreyer et al., 1980)。炎の後, 世 界各地から sodium phlogopite の化学組成が報告され，こ の名前はよく使われるようになりました。1998 年に雲母 の命名規約が公表され，鉱物名 aspidolite は, sodium phlogopite の代わりに，正式な種名として復活することになり ました。この規約に従うと, aspidolite は trioctahedral mica に属し, 理想化学式 $\mathrm{NaMg}_{3} \mathrm{AlSi}_{3} \mathrm{O}_{10}(\mathrm{OH})_{2}$ として定義され ました。

私が春日村産 magnesiosadanagaite 調べている時に， これに随伴する phlogopite の中に Kよりも Na が多い部分 があることに気がつきました。詳しい組織を調べるため に反射電子像を見たところ，明暗の細かな帯の集合体が 観察されました。明るい部分は K に富む部分で, phlogopite でした。暗い部分は $\mathrm{Na}$ に富む部分で，定量分析の結 果, $\mathrm{Si}$ に乏しい $(\mathrm{Si}=2.56 \mathrm{apfu})$ けれども, aspidolite に相 当することが判明しました。光こでこの aspidolite を詳し く調べることにしました。この時もこの鉱物は新鉱物 (と いうか種として確定されていない鉱物) という認識は全く ありませんでした。いろいろと文献を調べてみると X 線 のデータは合成物の粉末 X線回折データ(あまりよいデー タではない)だけしかないことが分かり, aspidolite の crystallography は重要のようだと思いました。乥こでまた 科博の方々に状況を説明して, 2003 年 7 月から共同研究 していただけることになりました。ほどなく宮脇先生か ら粉末 X線回折データが送られてきました。しかし標本 から分離した試料はすべて aspidolite と phlogopite とが混 在していたため, 弚れは両者の回折ピークが重なった データでした。A Aspidolite の完全な粉末 X 線回折データは ないので, phlogopite のデータから推定するほかありませ
ん。送られてきた表には c 軸の長さは phlogopite の光れの 97\% であると仮定して, aspidolite のd 值が計算されてい ました。実測値と計算值とを一生懸命見比べて対応を試 みたのですが, 明らかに対応しないピークがいくつも存 在し困惑してしまいました。また雲母にはポリタイプが ありますから，いろいろなポリタイプで対応を試みまし たが, どうしても対応しないピークが依然存在し，完全 に行き詰ってしまいました。9月の学会の際，宮脇先生と $\mathrm{X}$ 線データの解釈について相談し，「高分解能透過型電子 顕微鏡 (HRTEM) でポリタイプだけでも決定しましょう」 ということになり，宮脇先生から東京大学の小暮敏博先 生を紹介していただき，幸いにも先生は HRTEM 分析を 了解していただきました。11 月に分析結果が送られてき ました。光れには $\Gamma$ phlogopite は $1 M$, aspidolite については $\mathrm{Na}$ 層間イオンを挟む上下の四面体層が面内方向でずれて おり従来知られている雲母の層間構造とは異なっている」 と書かれていました。弚の後の小暮先生の研究により層 間のずれの方向により, 二つの新しいポリタイプ $(1 M$ と $1 A$; 両者とも $2: 1$ 層内の上下の四面体シートのずれの方向 は一定) があることが分かり，この層間構造を取り入れた aspidolite の構造モデルから計算される粉末 X 線回折パ ターンは実測値とよく合うことが示されました (Kogure et al., 2004)。Aspidolite の残された仕事は, 粉末 X線回折 データから phlogopite と aspidolite のピーク位置を読み取 り，各ピークに指数を配当することです。今度は phlogopite-1Mのパターンと aspidolite構造モデルから導かれるパ ターンという比較するものか確定しているので方針は明 快です。しかし実験により得られたピークの多くは phlogopite のピークと aspidolite のピークが重なったものなの で, 波形解析を行ってピークを分離しなければならずか なり面倒な作業です。正確なピーク位置を決定するため， 標準試料をまぶして再度 X線データを宮脇先生に取得し ていただきました。この宮脇先生の実験データと小暮先 生の計算データとを比較する日々か続きました。2004 年 の夏ごろに宮脇先生と共に波形分離作業を行い, やっと 各 $\mathrm{d}$ 值に指数を与えることができました(ただし，高角側 はピーク数が多すぎて断念)。特に三斜型のものはピーク 数が多く作業は本当に大変でした。これでデータはすべ て光ろったので aspidolite の記載論文の原稿を作成しまし た。この頃松原先生から「aspidolite はタイプ標本がないこ とや，X線データがない等あやふやな点が多い。新鉱物・ 鉱物名委員会に aspidolite の再定義の申請をしてはどうか?」 とのコメントをいただきました。乥こで再定義の申請書 を作ろうとしたのですが，うまく作ることができません。 こういう提案をする場合はタイプ標本を見つける努力を し, タイプ標本からデータを出すよう指摘されます。雲 母命名規約では aspidolite のタイプ標本の指定はなく， aspidolite のタイプ標本があるのかないのかが分からなく なってきたからです。私は新鉱物・鉱物名委員会の国内委 員であるので, 毎月新鉱物の申請書に目を通します。 
ちょうど光の頃チェックしていた申請書の中に角閃石の

一種である ferroholmquistiteがありました。光こには「角 閃石命名規約では ferroholmquistite という名前は定義され ているが，X線データを含む鉱物種としての記載はこれ まて報告されていないので，ここに申請する」というよう なことが書かれていました。これを読んで光の状況は aspidolite の場合と同じであることに気がつきました。 Aspidolite もこれと同樣に新鉱物の申請書を提出したほう が分かりやすい提案になると考えました。松原先生と宮 脇先生に相談したところ了解を得ることができ, 申請書 を新鉱物·鉱物名委員会に送り，2005 年 2 月に承認されま した。

\section{IV.おわりに}

このように magnesiosadanagaite と aspidolite を種として 確立する仕事は，私一人の力ではなんともすることがで きなかったわけであり，多くの方々の知恵と技術に助け られ，なんとか完成することができたわけです。標本提 供者ならびに共同研究者の方々に深く感謝いたします。

\section{引用文献}

Banno, Y., Miyawaki, R., Kogure, T., Matsubara, S., Kamiya, T. and Yamada, S. (2005): Aspidolite, the Na analogue of phlogopite, from Kasuga-mura, Gifu Prefecture, central Japan: description and structural data. Mineral. Mag., 69, 1047 1057.

Banno, Y., Miyawaki, R., Matsubara, S., Makino, K., Bunno, M., Yamada, S. and Kamiya, T. (2004): Magnesiosadanagaite, a new member of the amphibole group from Kasuga-mura, Gifu Prefecture, central Japan. Eur. J. Mineral., 16, 177 183.

Kogure, T., Banno, Y. and Miyawaki, R. (2004): Interlayer structure in aspidolite, the $\mathrm{Na}$ analogue of phlogopite. Eur. J. Mineral., 16, 891-897.

Schreyer, W., Abraham, K. and Kulke, H. (1980): Natural sodium phlogopite coexisting with potassium phlogopite and sodian aluminian talc in a metamorphic evaporite sequence from Derrag, Tell Atlas, Algeria. Contrib. Mineral. Petrol., 74, 223-233.

Shimazaki, H., Bunno, M. and Ozawa, T. (1984): Sadanagaite and magnesio-sadanagaite, new silica-poor members of calcic amphibole from Japan. Amer. Mineral., 69, 465-471.

von Kobell, F. (1869): Uber den Aspidolith, ein Glied aus der Biotit- und Phlogopit-Gruppe. Sitzungsber. Bayer. Akad. Wiss., 1, 364-366. 